\title{
Konfliktnost med mladostniki in starši: razvojno psihološki vidiki in sistemski vidik konfliktnosti v družini
}

\author{
Sonja Čotar Konrad* \\ Pedagoška fakulteta, Univerza na Primorskem
}

Povzetek: Problematika konfliktnosti med mladostnikom in starši je kljub porastu števila raziskav v tujini v Sloveniji še vedno relativno neraziskano področje. Aktualnost konfliktov v družini odraža tudi naraščajoče število agresivnih izražanj družinskih sporov v slovenski družbi, ki s tem dnevno postavlja znanost pred nove strokovne izzive. V članku najprej opredelimo konfliktnost v družini in pojem ločimo od drugih sorodnih pojmov. Prispevek prinaša tudi pomembna teoretična in empirično podprta izhodišča za razumevanje razlogov konfliktnosti v družini, natančneje konfliktnosti med mladostnikom in starši. Kritično predstavljamo razvojno psihološki vidik konfliktov med mladostnikom in starši, kjer soočamo in ocenjujemo štiri danes aktualne možne perspektive razvojno-psihološke razlage konfliktnosti: psihoanalitični vidik, socio-biološki, kognitivno razvojni in socio-relacijski vidik. Nazadnje pa v prispevku osvetlimo konfliktnost med mladostniki in starši kot element spremembe celotnega družinskega sistema skozi prizmo soočanja družine s stresom v skladu s Burr-Kleinovim modelom in omenjen model ovrednotimo na osnovi hipotetično predstavljenega primera delovanja družine.

Ključne besede: konflikti, družinski odnosi, mladostniki, starši, stres

\section{Conflict between adolescents and parents: Developmental and systemic perspectives of conflict in family}

\author{
Sonja Čotar Konrad \\ Faculty of Education, University of Primorska
}

\begin{abstract}
Despite the growing number of studies on family conflict abroad this issue still remains relatively unexplored in Slovenia. The importance of this issue is also evident from the increasing incidence of aggressive behaviour in family disputes in the Slovenian society. This represents new challenges science is faced with daily. Firstly, this paper tries to define the concept of family dispute and to separate it from other related concepts. Secondly, we provide a valuable theoretical and empirical understanding of reasons that determine conflict in the family, and more specifically the conflict between adolescents and their parents. The article critically points out the psychological and developmental aspect of the conflict between adolescents and their parents, where four possible developmental psychological perspectives and interpretations of conflicts in family are confronted and evaluated: the psychoanalytic perspective, the socio-biological, the cognitive developmental and the sociorelational aspects. Finally, the article tries to illuminate conflict in family as an element of change of the entire family system through the prism of family coping with stress adopting the Burr-Klein model (1994) and to evaluate the model on the basis of a hypothetically presented case of family functioning.
\end{abstract}

Key words: conflicts, family relations, adolescents, parents, stress

\footnotetext{
${ }^{*}$ Naslov/Address: dr. Sonja Čotar Konrad, Pedagoška fakulteta, Univerza na Primorskem, Cankarjeva 5, 6000 Koper, e-mail: sonja. cotarkonrad@pef.upr.si
}

Članek je licenciran pod pogoji Creative Commons Attribution 4.0 International licence. (CC-BY licenca).

The article is licensed under a Creative Commons Attribution 4.0 International License (CC-BY license). 


\section{Opredelitev obravnavanega problema in namena prispevka}

Konfliktnost v družini je tematika, ki je danes še posebno aktualna in pred stroko postavlja vedno nova vprašanja. Analiza doslej objavljenih študij na Slovenskem pokaže primanjkljaj tako na področju jasnega definiranja pojma konfliktnosti v družini kot tudi pomanjkanje enoznačnih empiričnih podatkov s področja konfliktnosti med mladostnikom in starši. Jedrni problem obravnave in namen prispevka je kritično predstaviti in analizirati razlage konfliktnosti med mladostnikom in starši z vidika nekaterih danes v svetu aktualnih teoretično-empiričnih izhodišč: psihoanalitičnega vidika, sociobiološkega vidika, kognitivno razvojnega vidika in socio-relacijskega vidika. $\mathrm{V}$ prispevku bomo v okviru posameznega vidika razlage mladostniške konfliktnosti s starši medsebojno integrirali dosedanja spoznanja in kritike posamezne perspektive. Primerjavo in ovrednotenje nekaterih v tuji literaturi pogostih razumevanjih in pojasnjevanjih narave konfliktnosti med mladostnikom in starši bomo nadgradili s celostnim sistemskim pristopom razumevanja družinske dinamike. V skladu s sistemskim vidikom dojemanja družine bomo s pomočjo pri nas še neznanega Burrovega in Kleinovega modela (Burr in Klein, 1994) soočanja družine s stresom predstavili celostni pristop k razumevanju konfliktnosti v družini in na osnovi predstavitve hipotetičnega primera družinske konfliktnosti ovrednotili tudi njegovo nadaljnjo uporabno vrednost.

\section{Opredelitev konfliktnosti v družini}

Kljub mnogim poskusom opredeljevanja ostaja konfliktnost danes še vedno relativno nejasen pojem, pri čemer pregled literature (npr. Emery, 1992; Jaycox in Repetti, 1993) pokaže, da ostaja pojem 'konfliktnost v družini' zaradi svoje kompleksnosti še bistveno bolj neopredeljen. Ena izmed opredelitev konfliktnosti v družini opisuje konfliktnost $\mathrm{z}$ vedenji med družinskimi člani, ki se pojavljajo na intervalu od verbalnega izražanja nestrinjanja prek kriticizma pa vse do dejanj fizične agresije (Jaycox in Repetti, 1993). Emery (1992) trdi, da ima konflikt v družini v osnovi enako temeljno strukturo kot druge oblike socialnih konfliktov, vendar pa se pomembno razlikuje vsaj v treh vidikih: (1) pogostosti - zaradi večje fizične prisotnosti, nujne delitve nalog in dolgoročnega sodelovanja članov družine je konflikt v družini pogostejši in se mu družinski člani težje izognejo; (2) normativnosti - zaradi dinamike medsebojnih odnosov pomeni običajno in normativno posledico prehodov $\mathrm{v}$ individualnem razvoju posameznika in skupinskem razvoju družine; (3) funkcionalnosti - zaradi svoje socialne, čustvene in praktične funkcije pa je konflikt $\mathrm{v}$ družini nosilec dodane vrednosti in velikega vpliva na posameznika, njegove medosebne odnose in družbo nasploh. Vidimo lahko, da omenjene tri dimenzije Emeryjeve opredelitve bolj kot na strukturo konflikta $v$ družini opozarjajo na njegovo vsebino in funkcijo. Nekoliko bolj se na samo strukturo konflikta v svoji zgodnejši opredelitvi osredotoči Shantz (1987), ki meni, da je konflikt časovno opredeljena socialna epizoda z nekaterimi razlikovalnimi značilnostmi, kot so (1) pojavnost in intenzivnost (pogostost in čustvena intenzivnost konflikta), (2) vsebina (tematika konflikta), (3) začetek konflikta in nasprotovanja (vedenja, s katerimi se prične konflikt), (4) rešitev (vedenja, ki zaključijo konflikt) in (5) izid (posledice) konflikta. Menimo, da pri dinamiki konflikta lahko jasno ločimo potek konflikta v vsaj treh stopnjah: začetek (Shantzejeva pojavnost in intenzivnost konflikta), nato vedenje, dogajanje med konfliktom samim (kamor lahko uvrstimo Shantzejevo opredelitev vsebine konflikta in začetka nasprotovanja v konfliktu) ter zaključek konflikta (ki se po Shantzeju kaže kot rešitev in izid konflikta). Sklepamo, da začetek, dogajanje in vedenje med konfliktom ter zaključek konflikta predstavljajo različne, vendar med seboj prepletene in povezane komponente konflikta, ki pa jih študije pogosto ne upoštevajo (npr. Adams in Laursen, 2007; Laursen in Colins, 1994). Dejstvoje, da osredotočanje na zgolj eno izmed karakteristik konflikta izkrivlja in neustrezno predstavlja značilnosti in funkcije konflikta. Kljub temu se mnoge študije danes doma in v tujini še vedno osredotočajo izključno na preučevanje frekvence, ..., torej pogostosti nesoglasij med mladostnikom in starši (npr. Adams in Laursen, 2007; Zupančič in Svetina, 19952002), čeprav so po drugi strani vse pogostejše kritike, da pogostost konfliktnosti daje zgolj omejeno informacijo o naravi in pomenu konflikta za mladostnike in njihove družinske odnose (Perry, Perry in Kennedy, 1992). Študije namreč kažejo, da sta stopnja izraženosti negativnih čustev in strategije reševanja konflikta dve komponenti, ki pomembneje in bolj učinkovito napovedujeta učinek konflikta kot pa njegova pogostost (Gottman, 1979; Laursen in Hartup, 1989). Tako menimo, da bi bilo bistveno bolje, če bi se v prihodnje raziskave osredotočale na preučevanje kvalitete, narave konfliktnosti v družini in izida konflikta ne pa zgolj njegove kvantitete.

\section{Teoretične perspektive razlage konflikta med mladostnikom in starši v okviru mladostnikovega razvoja}

Več študij je z različnimi teoretičnimi pristopi (npr. Deković, 1999; Paikoff in Brooks-Gunn, 1991) poskušalo razložiti spremembe $\mathrm{v}$ stopnji in pogostosti konfliktov na prehodu iz otroštva $\mathrm{v}$ mladostništvo in dalje med mladostništvom do zgodnje odraslosti, vendar do danes še ni bilo jasnega dogovora o tem, zakaj do teh sprememb pride (Steinberg in Sheffield Morris, 2001). Tako so si študije danes edine zgolj $\mathrm{v}$ dejstvu, da se $\mathrm{v}$ začetku mladostništva poveča stopnja prerekanja in prepiranja med mladostnikom in starši. Ob tem pa še vedno ni jasnega konsenza med raziskovalci, zakaj se tovrstni negativni odnosi med mladostnikom in staršem pojavijo. To dejstvo so skušali razložiti $\mathrm{z}$ več različnih perspektiv: 
psihoanalitičnega in neoanalitičnega vidika (Blos, 1979; Holmbeck, 1996), sociobiološkega vidika (Steinberg, 1989), s pomočjo kognitivno razvojnega (Collins, 1990) in sociorelacijskega vidika (Laursen in Collins, 1994). Omenjene perspektive bomo v nadaljevanju prispevka predstavili, medsebojno primerjali in kritično ovrednotili.

\section{Psihoanalitični in neoanalitični vidik}

Neoanalitiki (Blos, 1979) opisujejo psihološko in biološko preurejanje odnosov kot posledico fizične zrelosti mladostnika, pri katerem naj bi biološke spremembe $\mathrm{v}$ času pubertete ponovno obudile mladostnikove ojdipske želje. Slednje naj bi bile med mladostništvom vzrok za intrapsihične konflikte med idom in superegom. Konfliktnost ter sočasna težnja po ločevanju od staršev in nenavezanosti nanje sta po mnenju neoanalitikov normativen proces usklajevanja medsebojnih odnosov in zmanjšanja notranje tesnobe mladostnika.

O podobnem govori tudi Holmbeck (1996), ki pravi, da mladostniki na prehodu v mladostništvo začnejo zaznavati preveliko navezanost na starše (ang. overattached) in nediferenciranost od njih (ang. undifferentiated). Zato se morajo in želijo na tej stopnji svojega razvoja soočiti $\mathrm{z}$ lastno vpetostjo $\mathrm{v}$ družinske odnose. To pa ne pomeni zaostrovanja odnosa s starši, ampak predvsem novo definiranje in izpogajanje družinskih vlog na način, da ohranijo bližnje odnose tako s starši kot z vrstniki. Prav preusmeritev na odnose $\mathrm{z}$ vrstniki in $\mathrm{s}$ tem povečana čustvena oddaljenost od staršev (Blos, 1979) naj bi po mnenju neoanalitikov pomenila zmanjšanje notranje napetosti mladostnikov v odnosu do staršev. Konflikti, ki se pojavljajo med to redefinicijo vlog v družini, pa imajo predvsem funkcijo olajšati proces osamosvajanja mladostnika (Holmbeck, 1996).

$\mathrm{Na}$ osnovi omenjenega psihoanalitičnega razumevanja nastanka povečane konfliktnosti med mladostnikom in starši v obdobju prehoda iz otroštva v mladostništvo so avtorji trdili, da gre za t.i. »obdobje nevihte in groma « (ang. storm and stress, A. Freud, 1958, po Holmbeck, 1996). Vendar pa nasprotno nekemu splošno uveljavljenemu prepričanju t.i. »nevihtnega obdobja« ugotavljamo, da obstaja le malo empirične podpore za trditev, da bi bili za odnose med mladostniki in starši značilni skrajni nivoji konfliktnega vedenja. Celo več: študije kažejo, da obstajajo visoke stopnje konfliktov med mladostnikom in starši le $\mathrm{v}$ posameznih redkih primerih družin, pri čemer izjemno intenzivna konfliktnost pomeni navadno pomemben napovedni dejavnik tudi za neprilagojeno vedenje mladostnikov v zgodnjem mladostništvu nasploh (npr. Adams in Laursen, 2007; Montemayor, 1986). Na osnovi podanih empiričnih ugotovitev lahko zaključimo, da samemu začetku in nastopu pubertete le stežka pripišemo vzrok za povečano intenzivno konfliktnost v družini. Tovrstne zelo intenzivne konfliktnosti se v določeni meri pojavljajo zgolj pri posameznih družinah, obenem pa, kot pravi že Hill (1985, str. 235), stopnja teh vedenj ni »dovolj velika, da bi pomenila bazo za splošno razvojno teorijo« večine družin $\mathrm{z}$ mladostniki.

\section{Sociobiološki vidik}

Podobno izhodišče kot psihoanalitična perspektiva zagovarja tudi avtor sociobiološkega vidika. Steinberg $(1981,1987)$ v svojih študijah namreč ponuja evolucijsko ali t.i. sociobiološko razlago pojava konfliktnosti mladostnika v odnosih s starši, pri čemer meni, da se povečana količina konfliktov prav tako pojavi z nastopom pubertete mladostnikov. Omenjen vidik podkrepi z empiričnimi podatki v svojih zgodnjih študijah, kjer navaja (Steinberg, 1981), da je zgodnji cikel nastopa pubertete mladostnika povezan s povečano konfliktnostjo $\mathrm{v}$ odnosu $\mathrm{z}$ mamo. Na novo nastajajoče napetosti med mladostnikom in starši ne utemeljuje z ojdipskimi težnjami mladostnika, ampak jih opredeli v okviru svoje t.i. distančne hipoteze. Avtor distančno hipotezo utemeljuje s spremembo v kvaliteti odnosov(Steinberg, 1990), vkaterih sezrazvojempubertete pojavi večja čustvena oddaljenost med mladostnikom in starši, kar naj bi vodilo tudi $\mathrm{v}$ pogostejšo konfliktnost $\mathrm{v}$ teh odnosih. Omenjeno potrjujejo tudi nekateri drugi empirični podatki študij, ki večjo čustveno oddaljenost med zgodnjim mladostnikom in starši opisujejo kot manj psihološke bližine, manjšo pogostost in intenzivnost izražanja pozitivnih čustev med mladostnikom in starši (Collins, 1990), manj medsebojnega sprejemanja (Collins in Russel, 1991), srednji nivo konfliktne vpletenosti (Hill in Holmbeck, 1987), spremembe $\mathrm{v}$ naravi pravil in standardov ter manj mladostnikove vpletenosti $\mathrm{v}$ družinske aktivnosti (Holmbeck, Paikoff, Brooks-Gunn, 1995; Paikoff in Brooks-Gunn, 1991). Steinberg (1990) pa dodaja, da je prav zgodnja pubertetna zrelost tista, ki sproži povečano konfliktnost tega razvojnega obdobja. Ugotavlja namreč, da se zgodnja pubertetna zrelost deklet in zgodnja pubertetna zrelost fantov povezuje s povečano konfliktnostjo mladostnikov z mamo, a ne nujno tudi z očetom; obdobje povečane čustvene oddaljenosti ali začasnih motenj v odnosu med mladostnikom in starši pa se pojavi kmalu po nastopu pubertetnega razvoja pri fantih in dekletih, posebej še v diadi mati-hči (prav tam). Sočasno s pojavom evolucijskega pristopa pa kritiki te perspektive menijo (Laursen in Collins, 1994), da zaradi metodološke in konceptualne pomanjkljivosti Steinbergove raziskave ne ponujajo ustreznega argumenta za razumevanje sprememb v konfliktnosti med mladostniki in starši ob nastopu pubertete. Rezultati o t.i. distančni hipotezi, torej povečanju oddaljenosti mladostnikov od staršev kot posledici mladostnikove pubertetne zrelosti, naj bi bili namreč zbrani zgolj na osnovi poročanj mladostnikov o povečanju oddaljenosti od staršev (in ne tudi poročanj staršev). Zato nekateri avtorji opozarjajo, da gre pri tem predvsem za mladostnikov subjektivni občutek povečanja oddaljenosti od staršev in ne tudi za starševske izkušnje oddaljenosti od mladostnika (Deković, 1999; Steinberg, 1988). Vprašanja o metodoloških pomanjkljivostih, na katera opozarjajo kritiki sociobiološke perspektive, pa 
lahko deloma ovržemo tudi z nekaterimi empiričnimi podatki študij (Fletcher, Steinberg in Williams-Wheeler, 2004; Schwarz, Barton-Henry in Pruzinsky, 1985), ki poročajo, da so pri napovedovanju mladostnikovega ponotranjanja ali pozunanjanja konfliktnih vedenj (in $\mathrm{s}$ tem povečane konfliktnosti $\mathrm{v}$ odnosu $\mathrm{s}$ starši, op. avtorice) pomembnejši napovedni dejavnik predvsem mladostnikova subjektivna dojemanja starševskih praks in bistveno manj percepcije lastnih vzgojnih praks samih staršev. Strinjamo se, da podatki, pridobljeni s strani obeh vpletenih v odnos, prinašajo večjo objektivnost pridobljene informacije, ne moremo pa trditi, da bi bila predstavljena distančna hipoteza v okviru sociobiološke perspektive razumevanja povečane konfliktnosti v družini v celoti metodološko in vsebinsko sporna, če je v raziskavo vključen zgolj mladostnik sam.

Povzamemo lahko, da psihoanalitična in sociobiološka razlaga utemeljujeta naraščanje pojavnosti in intenzivnosti konfliktov z nastopom pubertetne zrelosti mladostnika in postavljata $\mathrm{v}$ vlogo 'sprožilca' konflikta mladostnika samega. Po drugi strani pa v nadaljevanju predstavljena socio-kognitivna perspektiva utemeljuje bodisi pogostejše konflikte bodisi več kompromisnih rešitev v odnosih med mladostnikom in starši kot posledico reorganizacije mentalnih sposobnosti mladostnika, torej s prehajanjem med stopnjami sociokognitivnega razvoja mladostnika (Younnis in Smollar, 1985).

\section{Kognitivno razvojni vidik}

Podobno kot psihoanalitična in sociobiološka perspektiva tudi kognitivno razvojni vidik vidi izhodišče konfliktnosti $\mathrm{v}$ razvojnih spremembah mladostnika samega. Za Selmana (1980) in Younnisa (Younnis in Smollar, 1985) pomeni namreč mladostnikov kognitivni razvoj izhodišče za 'prevetritev' mladostnikovega razumevanja starševskih zahtev. Mladostniki naj bi tako med mladostništvom vedno pogosteje želeli videti starše v luči enakopravnega in enakovrednega sogovornika. To pomeni mladostnikovo pogostejše izražanje zahtev po enakopravnem obravnavanju in vključevanju v pogovore o družinski problematiki, še posebej pa o vsebinah, ki se nanašajo na njegove lastne pravice, delovanje in vedenja $\mathrm{v}$ ali izven družinske skupnosti nasploh. Zagovorniki kognitivno razvojnega vidika menijo, da ima prav kognitivni razvoj posameznika pomembno vlogo pri tem, da mladostniki postajajo po eni strani vedno bolj odprti za razumevanje in sprejemanje psihološke realnosti drugega sogovornika (starša, op. avtorice), po drugi strani pa postajajo do starševskih zahtev vedno bolj kritični. Morebitno starševsko zavračanje povečane težnje mladostnika k recipročnosti in horizontalnosti v odnosu in vztrajanje pri konvencionalni poziciji, da je njihova odločitev in videnje problema edina pravilna in mogoča, legalna in legitimna, še povečuje konfliktnost v odnosu z mladostnikom. Spremembe in neujemanja v zaznavah in pričakovanjih, ki jih starši in mladostniki imajo o sebi in drug o drugem, lahko potemtakem v družini oblikujejo klimo medsebojnega neujemanja $\mathrm{v}$ različnih vidikih družinskega delovanja in v množici pomembnih družinskih tematik. Tako npr. Smetana $(1989,1995)$ dokazuje, da se odstopanja v razumevanju različnih družinskih tematik s strani mladostnikov in staršev povečajo prav ob nastopu zgodnjega mladostništva in se povezujejo $\mathrm{z}$ naraščanjem konfliktnosti v tem obdobju. Na ta način naj bi neujemanje med starševim in mladostnikovim videnjem problematik posegala $v$ povezave med razvojno spremembo (npr. težnjo po osamosvajanju mladostnika, op. avtorice) in stopnjo konfliktnosti med mladostnikom in staršem. Natančneje lahko kognitivno razvojni vidik razlage konfliktnosti v odnosu med mladostniki in starši utemeljimo npr. skozi vprašanje družinskega postavljanja pravil, kar predstavlja eno pomembnih dimenzij podpiranja mladostnikove samostojnosti (Sorkhabi, 2010). Način, kako starši že $\mathrm{v}$ začetku oblikujejo pravila in pričakovanja, ki se nanašajo na aktivnosti mladostnika, in način, kako starši omejujejo mladostnikovo samostojnost, pomeni enega izmed izvorov konfliktnosti med mladostnikom in starši. Raziskave, ki so se nanašale na preučevanje mladostnikove udeležbe pri odločanju v družini, ugotavljajo, da je t.i. skupno ali dvostransko odločanje, ko mladostniki sodelujejo v procesu sprejemanja odločitev, $\mathrm{v}$ primerjavi z enostranskim starševskim odločanjem ali enostranskim mladostnikovim odločanjem, povezano $\mathrm{s}$ pozitivnimi razvojnimi izidi mladstnika. Med temi študije omenjajo učno kompetentnost, visoko samospoštovanje, notranjo motiviranost, manjšo stopnja delinkventnosti, deviantnosti in manjšo stopnjo dojemljivosti za negativne vplive vrstnikov (Brown, Mounts, Lamborn in Steinberg, 1993; Fuligni in Eccles, 1993). Menimo namreč, da skozi družinsko postavljanje pravil starši dopuščajo ali omogočajo, da se mladostnik v skladu s svojo stopnjo kognitivnega razvoja postopoma uči razumevanja in medsebojne povezave več perspektiv in pričakovanj $\mathrm{v}$ smiselno oblikovana in socialno sprejemljiva družinska pravila. S tem krepi sposobnost lastnega odločanja in doseganja večje samostojnosti in neodvisnosti v življenju nasploh.

Glede na predstavljen vidik konfliktnosti v družini ocenjujemo, dakognitivnorazvojnaperspektivaopredeljuje vlogo konfliktnosti med mladostnikom in starši predvsem kot tvorno možnost družine, da po obdobju otroštva ponovno izpelje pogajanja o družinskih vlogah in odnosih - od bolj hierarhičnih v zgodnjem mladostništvu do bolj enakovrednih, enakopravnih $\mathrm{v}$ poznem mladostništvu (Adams in Laursen, 2007; Goossens, 2006; Grotevant in Cooper, 1985; Steinberg, 1990) - odnosov, ki z nastopom mladostništva postajajo v svoji vsebini in obliki kot strogo hierarhični docela nefunkcionalni. Nadalje pa kognitivno razvojni vidik vidi porast konflikta med mladostnikom in starši v kognitivni reorganizaciji mladostnika. Pri tem kognitivna perspektiva predvideva, da naj bi kognitivni razvoj mladostnika spodbudil revizijo mladostnikovega pojmovanja sebe in njegovih odnosov $\mathrm{z}$ drugimi. Kognitivna razvojna perspektiva tako poudarja predvsem nezveznost pojava konfliktnosti med mladostnikom 
in starši, saj meni, da hierarična razporeditev vlog v družini $\mathrm{v}$ otroštvu preprečuje možnosti za nastanek intenzivnejših konfliktnih odnosov med otrokom in staršem. V mladostništvu pa naj bi se zaradi kognitivne reoganizacije mladostnika in njegove težnje po večji enakopravnosti v odnosih pojav intenzivne konfliktnosti med mladostniki in starši bistveno povečal.

Predstavljen kognitivno razvojni vidik razumevanja sprememb $\mathrm{v}$ konfliktnosti med mladostniki in starši prinaša pomembno informacijo o vlogi miselnih reprezentacij mladostnika pri dojemanju in argumentaciji socialnih odnosov. Po drugi strani pa vidimo pomanjkljivost predstavljene perspektive predvsem v preveliki osredotočenosti zgolj na kognitivni vidik konflikta in neupoštevanje vloge sprememb v kvaliteti čustvene izraznosti mladostnikov in staršev v medsebojnih konfliktih.

Primerjava psihoanalitične, socio-biološke in kognitivno razvojne perspektive razumevanja porasta konfliktnosti med mladostnikom in starši na prehodu iz otroštva $\mathrm{v}$ mladostništvo pokaže, da je omenjenim perspektivam skupno dvoje: (1) izhodišče o nezveznosti pojava konfliktnosti v družini, torej predpostavka, da se večja in kvalitativno drugačna konfliktnost med mladostnikom in starši pojavi šele $\mathrm{z}$ začetkom mladostniškega obdobja, in (2) osredotočenost perspektiv na izvor konflikta $\mathrm{v}$ razvojnopsiholoških spremembah v mladostniku samem. Nasprotno zgoraj omenjenim vidikom razlage družinske konfliktnosti pa sociorelacijski vidik, ki ga predstavljamo v nadaljevanju, poudarja (1) kontinuiteto narave odnosov med mladostnikom in starši ter (2) vidi izvor nesoglasij med mladostniki in starši $\mathrm{v}$ medsebojnih relacijah, oziroma $\mathrm{v}$ obeh udeležencih konflikta in ne zgolj v mladostniku samem.

\section{Sociorelacijski vidik}

Sociorelacijska perspektiva gradi svoje teoretično izhodišče v teoriji izmenjave (Kelly, idr., 1983), ki pravi, da se odnosi oblikujejo, ko sta dve strani vpleteni v konsistentno nagrajujoče izmenjave. Bližina se razvije kot posledica stopnjevane količine vloženega kapitala v odnos in iz njega pridobljenih prednosti. Za razvoj in ohranjanje tesne povezanosti $\mathrm{v}$ odnosu je potrebna integracija posameznikovih ciljev in vedenj, kar pa $\mathrm{v}$ interakciji z drugo osebo neizogibno izzove konflikt. Vlaganje v odnos torej pomeni, da bo posameznik minimaliziral potencialno škodo, ki bi ob konfliktu lahko nastala, da bi še naprej ohranjal koristi iz obstoječega odnosa. Za mladostnike velja, da se njihovi tesni odnosi navadno nanašajo na starše in prijatelje. Za te relacije je značilna najvišja stopnja medsebojne povezanosti in soodvisnosti (Argyle in Furnham, 1982), kar mladostnikom vedno znova ponuja 'varno bazo' za raziskovanje zunanjega okolja. Zaznave in pričakovanja v tesnih odnosih (npr. s starši, op. avtorice) predstavljajo mladostniku posebne mehanizme varovanja in preprečevanja nenadnih fizičnih, socialnih in kognitivnih sprememb, ki bi lahko ogrozile njegov občutek varnosti in stabilnosti v odnosih s starši. Kljub temu da so nekatere spremembe v odnosih nujno potrebne za prilagajanje na nov (družinski, op. avtorice) razvojni kontekst, pa naj bi bil proces spreminjanja letega $\mathrm{z}$ vidika sociorelacijske perspektive postopen in kontinuiran (Collins, 1990). Laursen in Collins (1994) posledično ugotavljata, da obstajajo večje razlike $\mathrm{v}$ vedenju med konfliktom med različnimi tipi družinskih odnosov (npr. partnerski odnos, starševski odnos, op. avtorice) kot pa razlike glede na starost mladostnika. Avtorja namreč zagovarjata tezo, da naj bi se povečana konfliktnost $\mathrm{v}$ odnosih med mladostnikom in starši ne začela z nastopom mladostništva, ampak se - če je že prisotna - nadaljuje na osnovi težavnih odnosov med otrokom in starši že od otroštva dalje. Glede na omenjeno predpostavko o kontinuiteti narave (družinskih) odnosov zagovorniki sociorelacijskega vidika trdijo, da naj bi se vedenje mladostnika v družinskih interakcijah spreminjalo bolj kot posledica kvalitete odnosov samih in situacij, v katerih se konflikti pojavijo, kot pa posledica začetka pubertete ali sprememb v starosti mladostnika (Laursen in Collins, 1994).

Sociorelacijska perspektiva je v primerjavi z zgoraj omenjenimi perspektivami naredila korak naprej tudi pri vprašanju sprožilca in izvora konfliktnosti med mladostnikom in starši. Opozarja namreč, da je potrebno $\mathrm{v}$ raziskovanje konfliktnosti vključiti ne zgolj mladostnikove razvojnopsihološke značilnosti, ampak tudi vpliv in delovanje staršev $\mathrm{v}$ odnosih z mladostniki ter njihova prepričanja o mladostnikih. Slednje empirično potrjujejo tudi nekatere študije (npr. Smetana, 2005). Avtorica v skladu s teorijo socialnih področij (ang. social domain theory; Smetana, 2005) namreč ugotavlja, da se starševo poseganje na osebna področja mladostnikovega delovanja, npr. mladostnikov stil oblačenja, pričeske, mladostnikova izbira prijateljev, ipd. (in ne zgolj na področje moralnega, konvencionalnega ali bonitetnega delovanja, kjer mladostniku, npr. prepovedujejo tisto, kar je zanj ali njegovo okolico škodljivo) povezuje z visoko pogostostjo medsebojnih konfliktov in $\mathrm{s}$ težavami $\mathrm{V}$ psihosocialnem mladostnikovem prilagajanju (Smetana, Crean, Campione-Barr, 2005).

Vprašanjepovezanostimedkonfliktnostjoinstarševimi prepričanji o njihovih vlogah $\mathrm{v}$ odnosih $\mathrm{z}$ mladostniki navajajo tudi novejše študije (npr. Holmes, Bond in Byrne, 2008), ki se specifično nanašajo na značilnosti konfliktnosti med materami in mladostniki. Gre za to, da avtorji (prav tam) analizirajo t.i. epistemološke perspektive mater, njihova prepričanja o védenju in razmišljanju ter pojmovanja o samem sebi kot konstruktorju znanja, ki pomenijo širši kognitivni okvir prepričanj, ki jih usmerja pri razumevanju in odzivanju na svoje otroke (Siegel in McGilicuddy-DeLisi, 2002). Tovrstne epistemološke perspektive napovedujejo stil komunikacije in strategije reševanja konfliktov med materjo in mladostnikom (prav tam). Zato začne mladostnik ob usvajanju in razvijanju svoje lastne kognitivne perspektive pogosto dvomiti $\mathrm{v}$ avtoriteto, resnico, osebna mnenja, logičnost postavljenih 
družinskih in družbenih pravil, itd, torej vsebin, ki pomenijo pomemben del epistemološkega sistema prepričanj mater (in staršev nasploh, op. avtorice). Prepričanja staršev o vlogi posameznega družinskega člana posledično določajo, kako bodo na mladostnikove dvome in pobude odreagirali. Starši, ki so prepričani, da je znanje in védenje produkt medsebojne diskusije, analize in kompromisa, bodo najverjetneje odprti za mladostnikove predloge med konflikti, nasprotno pa bodo starši, ki vidijo svoje epistemološke sisteme kot zaprt in dokončen set nespremenljivih dejstev, za ideje in stališča mladostnikov manj tolerantni in manj dostopni. Ob tem tudi empirični podatki študij kažejo, da slednja skupina mater $^{1}$ z relativno zaprtim epistemološkim sistemom dejansko poroča o intenzivnejših konfliktih z mladostniki (Holmes, Bond in Byrne 2008).

Sociorelacijska perspektiva pomeni pomembno nadgradnjo prej predstavljenih perspektiv predvsem v točki, ko konfliktnost med mladostniki in starši razume kot vprašanje kvalitete relacij med udeleženci konflikta in pri iskanju izvora konfliktnosti ne izhaja iz enega samega sprožilca konfliktnosti (razvojnopsiholoških značilnosti mladostnika), ampak poudarja vlogo obeh udeležencev konflikta - mladostnika in starša. Po drugi strani pa sociorelacijska perspektiva, podobno kot psihoanalitična, sociobiološka in kognitivno razvojna perspektiva, v svoje razumevanje konfliktnih odnosov med mladostniki in starši pomanjkljivo vključuje vprašanje vloge in pomena ob konfliktih prisotnih relativno intenzivnih čustev med mladostnikom in starši.

Povzamemo torej lahko, da sociobiološka in neoanalitična razlaga sprememb v pojavnosti konfliktnosti glede na starost mladostnika predvidevata, da bosta pojavnost in intenzivnost konfliktnosti $\mathrm{v}$ odnosih med mladostnikom in starši naraščala kot posledica nastopa pubertetnega razvoja, medtem ko sociokognitivna perspektiva utemeljuje povečanje konfliktnosti $\mathrm{z}$ mladostnikovim kvalitativno drugačnim pojmovanjem relacij in argumentov za starševo vedenje. Sociorelacijska perspektiva pa nadalje predpostavlja, da če se že bodo pojavile z mladostnikovo starostjo povezane spremembe $\mathrm{v}$ odnosu, bodo te postopne in kontinuirane in posledica delovanja vseh vpletenih $\mathrm{v}$ konflikt med mladostniki in starši. Sklepamo, da je vsem perspektivam skupna interpretacija o konstruktivni vlogi konflikta v družini, in sicer, da pomeni konflikt v odnosu med mladostnikom in starši pot h konstruktivnim spremembam v družini in $\mathrm{k}$ večji diferenciaciji mladostnika od staršev (Cicognani in Zani, 2010). Vidik celostne sistemske razlage delovanja in vplivanja konflikta na družinske odnose kot celote pa smo zajeli z Burr-Kleinovim (Burr in Klein, 1994) modelom soočanja družine $\mathrm{z}$ družinskim stresom.

\footnotetext{
${ }^{1}$ Predmet raziskave je bil le odnos med mamo in mladostniki; očetje v študijo niso bili vključeni.
}

\section{Analiza konfliktnosti $\mathbf{v}$ družini s sistemskega vidika soočanja družine $z$ družinskim stresom}

Olson (1997, str. 261) meni, da se »vsi stresorji bodisi začnejo bodisi končajo v družini«. Pri tem pa družinske stresorje avtorji definirajo kot »diskretne življenjske dogodke ali tranzicije, ki vplivajo na družinsko enoto in sprožijo (ali imajo potencial sprožiti) spremembe v družinskem socialnem sistemu« (Olson, Lavee in McCubin, 1988, str. 19).

Menimo, da med tovrstne stresorje lahko uvrstimo tudi konfliktnost $\mathrm{v}$ družini, natančneje konflikt med mladostnikom in starši, ki ga analogno opredelimo kot družinski dogodek, ki vedno znova sproža najprej spremembe $\mathrm{v}$ odnosu med mladostnikom in staršem, nato pa tudi v družini in njenem delovanju na sploh. Zato bomo v nadaljevanju uporabili Burr -Kleinov model družinskega stresa in soočanja družine s stresorji na primeru soočanja s konfliktnostjo med mladostnikom in staršem. Tovrstne aplikacije Burr-Kleinovega modela ni doslej zaslediti niti $\mathrm{v}$ tuji niti slovenski literaturi.

Burrov in Kleinov model družinskega stresa (Burr in Klein, 1994) pomeni enega izmed novejših konceptov stresa v družini, ki sta ga opredelila na osnovi teorije skupin in teorije logičnih tipov (Watzlawick, Weakland in Fisch, 1974). Teorija delovanja skupine razlaga, kako se lahko spremembe pojavijo $\mathrm{v}$ nekem sistemu in kljub temu sistem ostaja in se ohranja kot celota, med tem ko teorija logičnih tipov opredeljuje, kako člani skupine izkušajo spremembe pri prehajanju iz nižjega logičnega nivoja delovanja skupine na višji logični nivo delovanja skupine. Z združevanjem posameznih elementov obeh teoretičnih ozadij sta avtorja predvidevala razvojno teorijo družinskega stresa, ki sloni na treh teoretičnih nivojih stresa. Burr in Klein (1994) sta izhajala iz predpostavke, da se bo družina ob soočanju s stresom navadno najprej skušala prilagoditi s specifičnimi, manjšimi in konkretnimi spremembami $\mathrm{v}$ posameznih družinskih procesih (npr. spremembe $\mathrm{v}$ nalogah posameznega družinskega člana, kot so prevzemanje odgovornosti mladostnika za del gospodinjskih opravil), šele nato se bo zatekla $\mathrm{v}$ globlje in bolj abstraktne spremembe $\mathrm{v}$ družinskem sistemu (npr. premislek o kvaliteti vzgoje, vrednotah družine, ipd.). Avtorja menita, da naj bi se stres pojavljal na enem izmed treh nivojev abstrakcije, prvem, drugem ali tretjem nivoju stresnosti. Če se družina odziva na stres na prvem nivoju (ang. level I stress), pomeni, da spreminja svoja pričakovanja glede posameznih družinskih vlog in modificira določena družinska pravila. Če so tovrstne spremembe učinkovite pri spoprijemanju s stresorji, družina preide $\mathrm{v}$ stanje okrevanja in prevzame nadzor nad delovanjem stresorja. Tak primer naj bi bil, na primer, rojstvo novega družinskega člana, pri čemer se spremembe v družinskih vlogah kažejo kot nove naloge, ki jih prevzameta oče in mati ter spremembe pravil kot dogovori o tem, kdo bo previjal, kdo hranil dojenčka, ipd. 
Večina družin se $\mathrm{s}$ tovrstnimi spremembami zadovoljivo in učinkovito sooča s stresorjem, ko pa so procesi prvega nivoja neučinkoviti, se družina sooči $\mathrm{z}$ bolj kompleksno situacijo, ki pomeni prehod na drugi nivo soočanja s stresom (ang. level II stress, Burr in Klein, 1994).

Delovanje družine na drugi stopnji stresnosti pomeni, da mora družina poseči po globljih spremembah v svojem delovanju, da bi se mogla bolj učinkovito soočiti s stresom. Navadno se tovrstni pristopi nanašajo na spremembe $\mathrm{v}$ odnosih med družinskimi člani. Tako mora, na primer, družina, ki vzgaja mladostnika, oblikovati nova pravila in pričakovanja za posamezne družinske vloge, kot so uvedba 'policijske ure', prenos posameznih nalog pri opravljanju gospodinjskih opravil na mladostnika, ipd. Družina mora prav tako ponovno opredeliti svoj odnos do discipline, odgovornosti in načina, kako bo pristopala do mladostnika. Namesto pričakovanja, da bo mladostnik samoumevno sledil novo postavljenim pravilom, morajo starši ponovno premisliti, kako se bodo z mladostnikom dogovarjali in kakšne bodo posledice neupoštevanja postavljenih pravil. Prav slednje navadno prinaša bistvene spremembe v odnosu med mladostnikom in starši. Prvotni odnos med staršem in otrokom, ko je bil starš vsemogočna figura in otrokov skrbnik, se spreminja v bolj enakovreden odnos med mladostnikom in starši, ki postajajo vedno bolj osebnostna avtoriteta.

Ko pa so procesi drugega nivoja neučinkoviti, je družina v težavnejši situaciji in mora pri svojem soočanju s stresorji preiti na tretji nivo delovanja (ang. level III stress, Burr in Klein, 1994). Družina, ki je prisiljena izkusiti tretji nivo soočanja $\mathrm{s}$ stresorji, je $\mathrm{v}$ celoti in $\mathrm{z}$ vsakim svojim delom prepojena s težavami in se v bistvu sooča $\mathrm{z}$ najbolj temeljnimi vprašanji svoje vrednostne orientacije in filozofije lastnega obstoja in delovanja družine. Tako se na primer starši, katerih mladostnik je obsojen na zaporno kazen zaradi mladostniškega kriminala, lahko počutijo poražene in preobremenjene kljub temu, da so skušali svojega otroka vzgajati po svojih najboljših močeh. Če se želijo učinkovito soočiti npr. s hudim stresom odhoda mladostnika v prevzgojni zavod ali zapor, se morajo psihološko odreči vsaj delu odnosa in čustvene povezanosti $\mathrm{z}$ mladostnikom in ponovno poiskati odgovore na vprašanja, kaj pomeni biti družina in biti starš v tovrstni situaciji. Burr in Klein (1994) menita, da mora družina, ki se s stresorji sooča na tretjem nivoju, poiskati tudi odgovore na temeljna moralna in religiozna vprašanja človekovega obstoja.

V skladu s predstavljenim modelom menimo, da se družina, ki se sooča s povečano stopnjo konfliktnost $\mathrm{v}$ odnosu med mladostnikom in starši, na tovrstni stresor navadno odziva predvsem na prvem ali drugem nivoju stresnosti. Predvidevamo, da družina na prvem nivoju stresnosti deluje predvsem $\mathrm{v}$ obdobju prehajanja iz otroštva $\mathrm{v}$ zgodnje mladostništvo, ko mladostnik postopoma in delno uveljavlja diferenciacijo od staršev. S prehajanjem v srednje mladostništvo pa se kot posledica mladostnikovega sociokognitivnega razvoja, a hkrati njegove neizkušenosti pri uveljavljanju lastnih zahtev, okrepi tudi mladostnikov konfliktni odnos s starši. Menimo, da je družina $\mathrm{v}$ tem obdobju mladostnikovega razvoja zaradi povečane težnje mladostnika po osamosvajanju in ločevanju od staršev, iskanju in redefiniranju svojega novega psihološkega prostora $\mathrm{v}$ družini, primorana delovati na drugem nivoju stresnosti. Če je družina potemtakem prej skušala s sorazmerno ustaljenimi procesi reševati morebitna nesoglasja med otroki in starši, pa mora v obdobju mladostništva tovrstne načine komunikacije ponovno reformulirati, spremeniti in redefinirati vloge družinskih članov ter ponovno postaviti novo, bolj enakovredno hierarhijo moči med njimi. Tudi na ta način konfliktnost med mladostniki in starši ohranja vlogo nosilca konstruktivnih sprememb $\mathrm{v}$ družini, o čemer poročajo mnoge študije tako pri nas kot tudi v tujini (npr. Adams in Laursen, 2007; Zupančič in Svetina, 1995-2002). Empirični podatki o družinskih odnosih v času mladostništva namreč konsistentno poročajo ne zgolj o destruktivni, ampak tudi o pomembno konstruktivni vlogi nesoglasij in konfliktnosti z vidika ponovnega pogajanja o družinskih vlogah in relacijah - od bolj hierarhičnih v zgodnjem mladostništvu do bolj egalitarnih in enakopravnih $\mathrm{v}$ poznem mladostništvu (Adams in Laursen, 2007; Goossens, 2006; Grotevant in Cooper, 1985; Steinberg, 1990). Čeprav študije kažejo, da je velika količina konfliktov za mladostnikov razvoj in nadaljnje prilagajanje škodljiva (Laursen in Collins, 1994), se raziskovalci danes strinjajo, da konflikt v zgodnjem mladostništvu, ki se navadno nanaša na obrobne vsakodnevne vsebine (npr. različna gospodinjska opravila, zunanji videz mladostnika, opravljanje domačih nalog, opravljanje šolskih zadolžitev, način preživljanja prostega časa, ipd.) (Allison in Schultz, 2004; Bosma, Jackson, Zijsling in Zani, 1996; Deković, 1999; Prinz, Foster, Ket in O'Leary, 1979), pomeni normativno in začasno motnjo, ki je predvsem funkcionalni dejavnik za spreminjanja družinskih odnosov. O podobnih rezultatih raziskav poročajo tudi slovenski avtorji (Košir, 2002; Puklek, 2001; Puklek Levpušček, 2001; Ule, 1995; Zupančič in Svetina, 1995-2002), ki pravijo, da se med mladostnikom in starši pojavljajo razhajanja glede pomembnih življenjskih vprašanj in vsakdanjih življenjskih problemov, da pa ti konflikti med mladostniki in starši niso veliki, temveč občasni do zmerno pogosti in navadno blage intenzitete (Zupančič in Svetina, 2004). Študije kažejo, da je zmerna količina konfliktov s starši povezana $\mathrm{z}$ boljšo sposobnostjo prilagajanja mladostnikov kot pa stanje brez ali s prepogostimi konflikti v družini (Adams in Laursen, 2007), po drugi strani pa avtorji dodajajo, da rezultati longitudinalnih raziskav kažejo, da zmerni konflikti ne prizadenejo kvalitete družinskih odnosov (Smetana, Metzger in Campione-Barr, 2004). Na osnovi omenjenih empiričnih podatkov sklepamo, da konfliktnost v družini med mladostnikom in starši najpogosteje eskalira zgolj do drugega nivoja stresnosti (Burr in Klein, 1994) in le redko, $\mathrm{v}$ izjemnih primerih preide na tretji nivo stresnosti.

Ovrednotenje Burr-Kleinovega modela (Burr in Klein, 1994) pokaže njegov pomemben doprinos k razlagi odzivov družine na stres. Model namreč predvideva 
kvalitativno spreminjanje medsebojnih odnosov družinskih članov glede na različne stopnje stresnosti, s katero se soočajo. Avtorja (prav tam) poudarjata spiralno stopnjevanje nabora vedenj, prepričanj in vrednot skozi tri nivoje soočanja družine s spremembami, ki jih mora družina spremeniti, da bi se mogla uspešno soočiti s težavami in uravnovesiti družinsko delovanje.

Obenem pa kritična analiza Burr - Kleinovega (Burr in Klein, 1994) modela soočanja družine s stresom razkrije vsaj dve pomembni pomanjkljivosti modela. Čeprav se na eni strani model naslanja na sistemsko paradigmo, pa v svoji opredelitvi kot prvo pomanjkljivost ugotovimo premalo natančno vključujevanje vseh ključnih pojmov, ki so značilni za sistemsko pojmovanje družine (kot so npr. povezanost, hierarhija moči, medsebojno sovplivanje podsistemov, komunikacija, ipd.). Ker model še vedno ostaja empirično nepreverjen, lahko na vprašanje o povezanosti med konfliktom $\mathrm{v}$ družini in njegovim vplivom na preostalo družinsko strukturo navajamo le rezultate nekaterih drugih študij. Tako npr. avtorji Gehring, Wentzel, Feldman in Munson (1990) poročajo, da konflikt $v$ družini prinaša spremembe $v$ povezanosti v smeri zmanjševanja kohezivnosti družinskih diad vpletenih v konflikt (npr. zakonskega para) ali družine kot celote. Nadalje še ugotavljajo, da se pojavljajo tudi spremembe $\mathrm{v}$ razporejanju moči $\mathrm{v}$ družini, torej spremembe $\mathrm{v}$ prilagodljivosti družine, in sicer $\mathrm{v}$ smeri, da tisti družinski člani, ki niso vpleteni v konflikt, poročajo o izgubi moči (vpliva), pri čemer ima konflikt med mladostnikom in materjo na tem področju največji učinek (prav tam). Sklepamo torej lahko, da prevzame diada, v kateri konflikt nastaja, večjo moč in vpliv za vnašanje sprememb $\mathrm{v}$ družino. Tako predvidevamo, da so v obdobju mladostništva, ko se pogostejše konfliktne relacije pojavljajo v diadi mladostnik-starš, prav te diade ključne nosilke sprememb v družini, v kateri prav ti odnosi določajo delovanje družine nasploh.

Druga pomanjkljivost modela pa se, podobno kot pri psihoanalitični, kognitivno razvojni, socio-relacijski in deloma tudi sociobiološki perspektivi, kaže v odsotnosti upoštevanja čustvene komponente konflikta med mladostniki in starši. Slednja namreč pomeni pomembno informacijo o kvaliteti medsebojnih odnosov in napoveduje vedenje med konfliktom ter morebitne spremembe v kvaliteti odnosov ob izidu konflikta.

\section{Zaključek in predlogi za nadaljnje raziskave}

Prispevek razjasnjuje področje konfliktnosti v družini s pomočjo štirih razvojno-psiholoških perspektiv in s sistemskega vidika soočanja družine s stresom. Analiza konfliktnih odnosov med mladostnikom in starši s pomočjo razvojno psiholoških elementov razvoja mladostnika pomeni danes pomemben korak k lažjemu razumevanju kompleksnosti družinskih odnosov. Novejše študije poudarjajo predvsem prednost sociorelacijskega pojmovanja odnosa med mladostnikom in starši, ki govori o postopnosti sprememb v stopnji in kvaliteti konfliktnosti ter zagovarja tezo, da se spremembe v odnos vnašajo tako s strani mladostnika kot s strani starša. Sociorelacijski vidik analize odnosa med mladostnikom in starši prinaša tudi pomembna izhodišča za razumevanje specifičnosti in narave konfliktnosti medsebojnih odnosov med mladostnikom in staršem glede na spol in starost mladostnika, posebej z očetom in posebej z mamo. Prav teze o specifičnosti odnosov v posamezni družinski diadi pomembno opozarjajo na to, da se je v preventivnem, terapevtskem ali mediacijskem delu $\mathrm{z}$ družinami potrebno posvetiti tako vsakemu podsistemu posebej kot tudi celotni družini skupaj, vendar pa podrobna predstavitev in analiza omenjenih specifičnih relacij znotraj družine presega namen in obravnavan problem tega članka.

Za celostno obravnavanje družine pa nam prispevek ponuja analizo konfliktnosti $\mathrm{v}$ družini $\mathrm{s}$ pomočjo sistemskega pristopa Burrovega in Kleinovega modela družinskega soočanja $\mathrm{z}$ družinskim stresom (Burr in Klein, 1994).

$\mathrm{Na}$ osnovi kritične analize štirih pristopov $\mathrm{k}$ obravnavanju konfliktnosti med mladostniki in starši menimo, da bi bilo potrebno tudi na Slovenskem bodoče raziskave na področju konfliktnosti med mladostniki in starši zasnovati posebej pozorno. Pri tem bi bilo potrebno upoštevati dejstvo, da smiselno informacijo o naravi konflikta ne daje zgolj merjenje pogostosti konfliktov in njegove vsebine (tematike konflikta), ampak bi bilo potrebno biti pozoren tudi na merjenje kvalitete konflikta, torej njegove intenzivnosti, prisotnosti valence in stopnje čustvene izraznosti družinskih članov ter poteka konflikta nasploh (torej vprašanje začetka, sprožilca konflikta, vedenja med konfliktom samim in izidom konflikta ter vplivom konflikta na kasnejše relacije med vpletenimi družinskimi člani).

Kot odgovor na vprašanje, zakaj se povečana konfliktnost med mladostniki in starši pojavi prav v obdobju mladostništva, bi bilo potrebno zasnovati longitudinalno raziskavo, ki bi omogočila spremljanje družinskih relacij $\mathrm{z}$ vključevanjem zaznav in čustvenih odnosov tako s strani staršev kot mladostnikov in bi skozi daljše časovno obdobje preverjala $\mathrm{v}$ teoriji navedene morebitne vzroke za večjo konfliktnost med mladostniki in starši (npr. pubertetna zrelost, spremembe v sociokognitivni stopnji razvoja mladostnika, ipd.).

Članek nenazadnje prinaša tudi pomembno aplikativno vrednost, saj s predstavitvijo različnih možnih vzročnih dejavnikov za razumevanje povečanja konfliktnosti med mladostniki in starši, opozarja na pomembnost različnih pristopov $\mathrm{k}$ obravnavi konfliktnosti $\mathrm{v}$ posameznih družinskih podsistemih (npr. mati - hči, oče - hči, ipd).

\section{Literatura}

Adams, R. in Laursen, B. (2007). The correlates of conflict: Dissagreement is not necessarily detrimental. Journal of Family Psychology, 21(3), 445-458.

Allison, B. in Schultz, J. B. (2004). Parent-adolescent conflict in early adolescence. Adolescence, 39, 101-119. 
Argyle, M. in Furnham, A. (1982). Sources of satisfaction and conflict in different long-term relationships. Journal of Marriage and the Family. 45, 481-493.

Bosma, H., Jackson, S. E., Zijsling, D. H. in Zani, B. (1996). Who has the final says? Decisions on adolescence behaviour within the family. Journal of Adolescence, 19, 277-291.

Blos, P. (1979). The adolescent passage. Madison, CT, ZDA: International Universities Press.

Brown, B. B., Mounts, N., Lamborn, S. D. in Steinberg, L. (1993). Parenting practices and peer group affiliation. Child Development, 64(2), 467-482.

Burr, W. R. in Klein, S. R. (1994). Reexamining family stress: New theory and research. Thousand Oaks, CA, ZDA: Sage Publications.

Cicognani, E. in Zani, B. (2010). Conflict styles and outcomes in families with adolescent children. Social development, 19(2), 427-436.

Collins, W. A. (1990). Parent-child relationship in the transition to adolescence: Continuity and change in interaction, affect and cognition. V R. Montemayor, G. Adams in T. Gulotta (ur.), From childhood to adolesscence: A transitional period? (str. 85-106). Beverly Hills, CA, ZDA: Sage.

Collins, W. in Russell, G. (1991). Mother-child and father-child relationships in middle adolescence: A developmental analysis. Developmental Review, 11, 99-136.

Deković, M. (1999). Parent-adolescent conflict: Possible determinants and consequences. InternationalJournal of Behavioral Development, 23(4), 977-1000.

Emery,R.E.(1992). Familyconflictand theirdevelopmental implications: A conceptual analysis of meanings for the structure of relationships. V C. Uhlinger Shantz in W. W. Hartup (ur.), Family conflicts and conflicts in child and adolescent development (str. 270-301). New York, NY, ZDA: Cambridge University Press.

Fletcher, A. C., Steinberg, L. in Williams-Wheeler, M. (2004). Parental influences on adolescent problem behaviour: Revisiting Stattin and Kerr. Child Development, 75, 781-796.

Fuligni, A. J. in Eccles, J. S. (1993). Perceived parentchild relationships and early adolescent's orientation toward peers. Developmental Psychology, 29(4), 622-632.

Gehring, T. M., Wentzel, K. R., Feldman, S. S. in Munson, J. (1990). Conflict in families of adolescents: The impact on cohesion and power structures. Journal of Family Psychology, 3(3), 290-309.

Goossens, L. (2006). The many faces of adolescent autonomy: Parent-adolescent conflict, behavioural decision-making, and emotional distancing. V S. Jackson, in L. Goossens (ur.), Handbook of adolescent development (str. 135-153). New York, NY, ZDA: Psychology Press.

Gottman, J. M. (1979). Marital interaction: Experimental investigations. San Diego, CA, ZDA: Academic Press.
Grotevant, H. D. in Cooper, C. R. (1985). Patterns of interaction in family relationships and the development of identity exploration in adolescence. Child Development, 56, 415-428.

Hill, J. P. (1985). Family relations in adolescence: Myths, realities and new directions. Genetic, Social and General Psychology Monographs, 111, 233-248.

Hill, J. P. in Holmbeck, G. N. (1987). Familial adaptation to biological change during adolescence. V R. M. Lerner in T. T. Foch (ur.), Biological-psychosocial interactions in early adolescence: A life span perspective (str. 207-223). Hillsdale, NJ, ZDA: Lawrence Erlbaum.

Holmbeck, G. N. (1996). A model of family relational transformation during the transition to adolescence: Parent-adolescent conflict and adaptation. V J. A. Graber, J. Brook-Gunn in J. C. Peterson (ur.), Transitions through adolescence: Interpersonal domains and context. (str. 167-199). Mahwah, NJ, ZDA: Lawrence Erlbaum Associates.

Holmbeck, G. N., Paikoff, R. L. in Brooks-Gunn, J. (1995). Parenting adolescents. V M. Bornstein (ur.), Handbook of parenting: Vol.1: Children and parenting (str. 91-118). Mahwah, NJ, ZDA: Lawrence Erlbaum.

Holmes, T. R., Bond, L. A. in Byrne, C. (2008). Mothers' beliefs about knowledge and mother-adolescent conflict.Journal of Social and Personal Relationships, 25 (4), 561-586.

Jaycox, L. H. in Repetti, R. L. (1993). Conflict in families and the psychological adjustment of preadolescent children. Journal of Family Psychology, 7(3), 344-355.

Kelly, H. H., Berscheid, E., Christensen, A., Harvey, J. H., Huston,T. L., Levinger, G., McClintock,E., Peplau, L. A. in Peterson, D. R. (1983). Close relationships. San Francisco, CA, ZDA: Freeman.

Košir, K. (2002). Povezanost med subjektivnim življenjskim zadovoljstvom ter odnosi mater do njihovih mladostnikov [Connection between subjective life satisfaction and mothers' relationships to their adolescents]. Psihološka obzorja, 11(1), 97-110.

Laursen, B. in Collins, W. A. (1994). Interpersonal conflict during adolescence. Psychological Bulletin, 115, 197-209.

Laursen, B. in Hartup, W. W. (1989). The dynamics of preschool children's conflict. Merril-Palmer Quaterly, 35, 281-297.

Montemayor, R. (1986). Family variation in parent adolescence storm and stress. Journal of Adolescent Research, 1, 15-31.

Olson, D. H. (1997). Family stress and coping: A multisystem perspective. V S. Dremann. The family on the treshold: Trends and implications of the 21st century (str. 259-282). Mahwah, NJ, ZDA: Lawrence Erlbaum.

Olson, D. H., Lavee, Y. in McCubbin, H. I. (1988). Types of families and family response to stress across the 
family life cycle. V D. M. Klein in J. Adams (ur.), Social stress and family development (str. 16-43). New York, NY, ZDA: Guilford Press.

Paikoff, R. L. in Brooks-Gunn, J. (1991). Do parent-child relationships change during puberty? Psychological Bulletin, 110, 47-66.

Perry, D. G., Perry, L. C. in Kennedy, E. (1992). Conflict and the development of antisocial behavior. V C. U. Shantz in W. W. Hartup, (ur.), Conflict in child and adolescent development (str. 301-329). Cambridge, VB: Cambridge University Press.

Prinz, R. J., Foster, S. L., Kent R. N. in O’Leary, K. D. (1979). Multivarate assesment of conflict in distressed and non-distressedmother-adolescent dyads. Journal of Applied Behavior Analysis, 12, 691-700.

Puklek, M. (2001). Razvoj psihološkega osamosvajanja mladostnikov $v$ različnih socialnih kontekstih (Neobjavljenadoktorskadisertacija)[The development of adolescent psychological individuation in different social contexts (Unpublished doctoral thesis)]. Filozofska fakulteta Univerze v Ljubljani, Slovenija.

Puklek Levpušček, M. (2001). Razvoj vedenjske avtonomije mladostnikov $\mathrm{v}$ odnosu do staršev in vrstnikov [The development of behavioural individuation of adolescents in relation to parents and peers], Anthropos, 1(3), 63-74.

Selman, R. L. (1980). The growth of interpersonal understanding. New York, NY, ZDA: Academic Press.

Schwarz, J. S., Barton-Henry, M. L. in Pruzinsky, T. (1985). Assessing child-rearing behaviors: A comparison of ratings made by mother, father, child and sibling on CRPBI. Child Development, 56, 462-479.

Shantz, C. U. (1987). Conflict between children. Child development, 58, 283-305.

Siegel, I. E. in McGilicuddy-DeLisi, A. V. (2002). Parental beliefs are cognitions: The dynamic belief system model. V M. H. Bornstein (ur.), Handbook of parenting: Vol. 3. Being and becoming a parent (2. izd., str. 485-508). Mahwah, NJ, ZDA: Lawrence Erlbaum.

Smetana, J. G. (1989). Adolescents' and parents' reasoning about actual family conflict. Child Development, 60, 1052-1067.

Smetana, J. G. (1995). Parenting styles and conceptions of parental authority during adolescence. Child Development, 66, 299-316.

Smetana, J. G. (2005). Adolescent-parent conflict: Resistance and succession ad developmental process. V L. Nucci (ur.), Conflict, contradiction, and contrarian elements in moral development and education (str. 69-91). Mahwah, NJ, ZDA: Lawrence Erlbaum.

Smetana, J. G., Crean, H. F. in Campione-Barr, N. (2005). Adolescents' and parents' changing concepts of parental authority. New directions for child and adolescent development, 108, 31-46.
Smetana, J. G., Metzger, A. in Campione-Barr, N. (2004). African American adolescents' relationships with parents: Developmental transitions and longitudinal patterns. Child Development, 75, 932-947.

Sorkhabi, N. (2010). Sources of parent-adolescent conflict: Content and form of parenting. Social Behavior and Personality, 38(6), 761-782.

Steinberg, L. D. (1981). Transformations in family relations at puberty. Developmental Psychology, 17, 833-840.

Steinberg, L. D. (1987). Impact of puberty on family relations: Effect of pubertal status and pubertal timing, Developmental Psychology, 23(3), 451-460.

Steinberg, L. D. (1988). Reciprocal relations between parent-child distance and pubertal maturation. Developmental Psychology, 24, 122-128.

Steinberg, L. D. (1989). Pubertal maturation and parentadolescent distance: An evolutionary perspective. V G. R. Adams, R. Montemayor in T. P. Gullota (ur.), Biology of adolescent behavior and development (str. 71-97). Newbury Park, CA, ZDA: Sage.

Steinberg, L. D. (1990). Interdependence in the family: Autonomy, conflicts and harmony in the parentadolescent relationship. V S. S. Feldman in G. R. Eliot (ur.), At the treshold: The developing adolescent (str. 833-840). Cambridge, MA, ZDA: Harvard University Press.

Steinberg, L. in Sheffield Morris, A. (2001). Adolescent development. Annual Review of Psychology, 52, 83-110.

Ule, M. (1995). Odraščanje v Sloveniji [Growing up in Slovenia]. V M. Ule in V. Miheljak (ur). Pri(e)hodnost mladine [The future of youth] (str. 63-134). Ljubljana: DZS.

Watzlawick, P., Weakland, J. in Fish, R. (1974). Change: Principles of problem formation and problem resolution. New York, NY, ZDA: W.W. Norton.

Younnis, J. in Smollar, J. (1985). Adolescent relations with mothers, fathers and friends. London: University of Chicago Press.

Zupančič, M. in Svetina, M. (1995-2002). Rezultati intervjujev o odnosih med mladostniki in družino [The results of the interviews on relationships between adolescents and family]. Neobjavljeno gradivo na katedri za razvojno psihologijo, Filozofska fakulteta Univerze v Ljubljani.

Zupančič, M. in Svetina, M. (2004). Socialni razvoj v mladostništvu [Social development in adolescence]. V L. Marjanovič Umek in M. Zupančič (ur.), Razvojna psihologija [Developmental psychology] (str. 589612). Ljubljana, SLO: Znanstveno raziskovalni inštitut Filozofske fakultete. 